\title{
Rehabilitating, repairing and restoring against demolishing, tearing down and destroying: the recovery of the military fort for the Santa Pola town museum
}

\author{
A. Martínez-Medina \& P. J. Juan Gutiérrez \\ University of Alicante, Spain
}

\begin{abstract}
This communication develops the process of interventions of the Renaissance fortress of a new plant built in 1554-57 in Santa Pola. It is one of the earliest examples built with reference to military architecture theoretical treaties (XV$\mathrm{XVI}$ ) and best preserved. The study runs its own story from its initial military use, through the use of civil equipment until the final cultural and Museum Center. First, the project of Italian origin is examined and its use as barracks for troops for a duration of three centuries (1557-1850), pointing out the architectural constants of war machinery in a defense position and its origin as a rainwater collector and cistern: a perfect square with two bastions in which a plan of the uprising is preserved (1778). Secondly, we study the changes in the mentioned architecture throughout a century and a half (1850-1990) after its change of ownership (from the state to the municipality), and as a result of the new use as a city hall and public endowment: a market and health and leisure centre, which meant the demolition of defensive elements and the opening up to the outside of the inner parade ground. And thirdly, the new transfer of the municipal offices brings in the beginning of a project of transformations (19902015) that retrieves the demolished elements at the same time as it assigns the entire fort for a cultural centre: exhibition, research and history museum, promoting the identity between the citizens and the building which stands in the foundations of their city. The conclusions take us through an interesting route that goes from the approach of defensive tactics, its use as administrative headquarters to the current cultural policy of preservation. In addition, all the known plans of the fort are recovered (of military, civil and cultural use), some
\end{abstract}


unpublished, as well as the project of the North wing that has guided the last operation and which has been set as a pattern of reference.

Keywords: Renaissance fortresses, military architecture, heritage rehabilitation, Santa Pola museum.

\section{Introduction: five centuries in the life of the military fort}

\subsection{The necessary research prior to the intervention}

This paper addresses the architectural intervention on the castle-fortress of Santa Pola between 1998 and 2003 (Figure 1). For the last century and a half - from 1850 to circa 1990 - this ancient military fort built in the 16th century served as a town council building. After this period, the building became an almost empty shell. This Renaissance fortress was innovative in its time in introducing modern defensive systems. Although declared a monument in 1949, this recognition did not go much beyond preventing its demolition. By the end of the 1980s, before the municipal public officials left the old fort, a plan was formulated to make it a cultural center. To achieve this conversion various partial actions were undertaken on the building as a whole. A team of technicians working with common objectives continuously assessed the history and archaeology of the site. (The team of technicians that were involved in the rehabilitation works of the North Wing of the Castle-Fortress of Santa Pola, between 1998 and 2003 are A. Martínez-Medina and M. Sempere Valero (architects), J. García Fernández and P. Agulló Piñol (quantity surveyor), M. Candela Jiménez and C. Suay Ramos (engineers) and M.J. Sánchez Fernández (archaeologist). This rehabilitation work received a Mention of the Jury, Juan Vidal Architecture

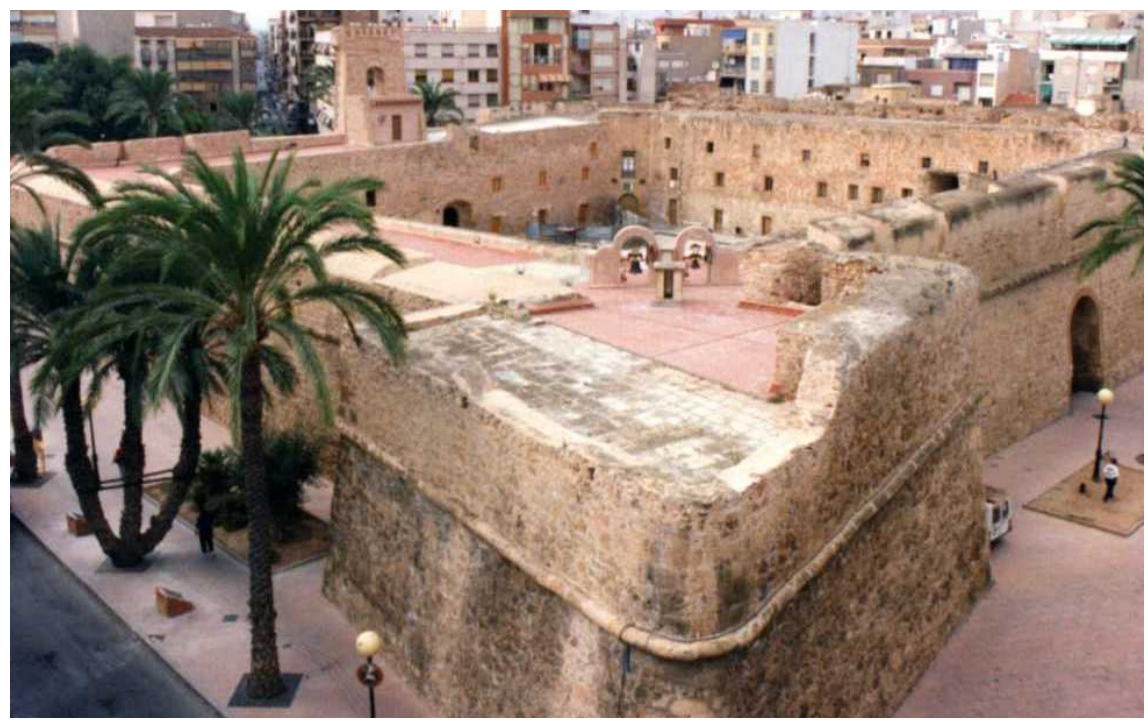

Figure 1: View of the Santa Pola fortress from the South-East (circa 1990). 
Awards of the Diputación de Alicante.) The intervention works demanded a concentration of thinking and decisions to apply current techniques alongside understanding traditional construction systems. The only way to recover the memory of the society that erected the fort, and to project it into the future, was through a complete understanding of the building. Therefore, investigation was an absolute necessity before intervening.

\subsection{The Renaissance fortress: military, civil and cultural (1557-1850-1990)}

The castle-fortress, constructed to operate between 1554 and 1557 by the Viceroy of the ancient Kingdom of Valencia, Bernardino Cardenas, was designed as a defensive war machine [1] with a garrison of soldiers living inside. The protective function against the Berber raids was the main reason for construction, however it was also intended to ensure trading and fishing operation of the natural harbor of the bay [2]. This company was not an isolated fact of its time, it constituted one of the links in this chain of renovation and construction works of fortification, along the Mediterranean coast, carried out by the Austrias family in the 16th century in order to protect against the skirmishes that the Ottoman ships carried out on these shores, shielding the border through this network of defences.

The military program developed in the coastal region of Valencia included the reinforcement of the existing medieval towers, the execution of new towers, watchtowers, the reinforcement of the walls and increasing strategic capacity, so that, it was a vigilant network of defences [3]. This way, the defensive system of the maritime boundary was articulated as an instrument of centralized control that prevented attacks from the enemies $[4,5]$. The Fort of Santa Pola and the surrounding watchtowers were inserted as rungs of this ladder of information that acted as a Sentinel and coat of arms of absolute power embodied in the figure of the Spanish monarch. (More information can be found in $[6,7]$.) There is no doubt that original traces of the Fort followed ideal schemes that were reflected in Italian architecture and engineering agreements, so it is no coincidence that the formal and functional similarity exists between the theoretical models proposed by the experts of the 15th and 16th centuries and the Fort of Santa Pola (see $[8,9]$ ). (The similarity between the Fort of Santa Pola and the Project for the Castelo di L'Aquila (1534) can be seen in [10].) Its square plan brings together the Renaissance ideal of unity, centrality and symmetry with a geometry that modulates, and imposes order to the structure and the space. Not surprisingly, this Fort is "one of the first - if not the first - work of modern military architecture" [11] built on the coast of Alicante and the best preserved regarding its traces of primitive (as credited with its resemblance to the Fort of Bernia of 1562) and consisting of the repeated addition of 28 residential townhouses along its four walled fronts.

For three centuries it remained in military use. In 1778 plans of the first known uprising were drawn up $[12,13]$ - there are other plans, see [14]); they described the property accurately (Figure 2), where it is revealed that the roof is an inclined plane since the Fort was a war machine defense position to collect and store rainwater for the survival of the garrison. In any case, the defensive 


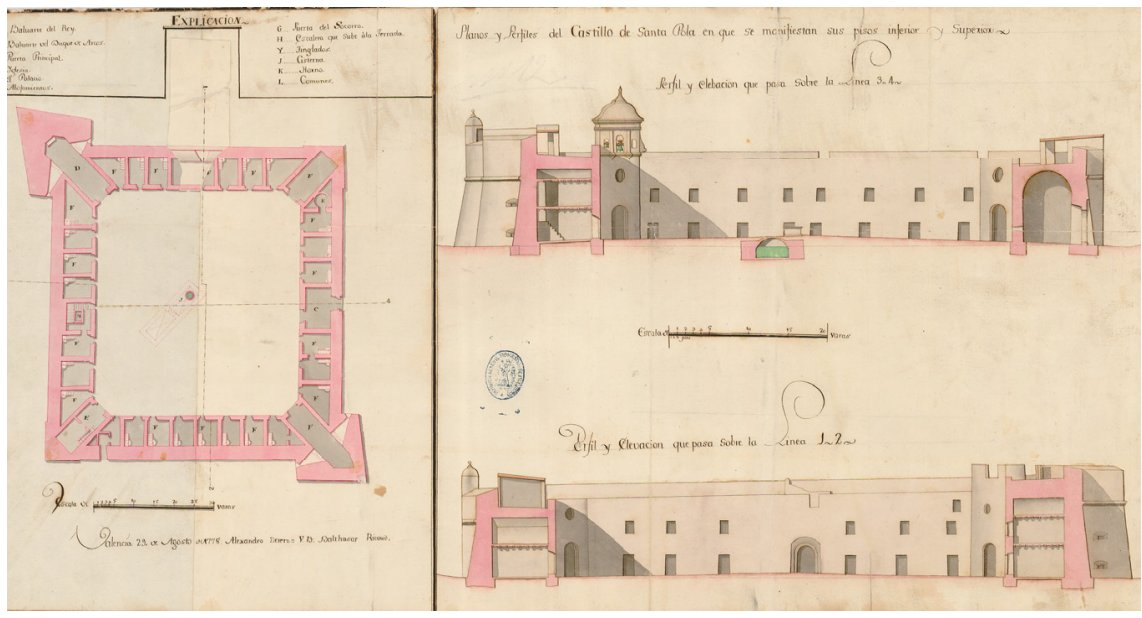

Figure 2: $\quad$ Plant and sections of the fortress hoist by Alejandro Deretx in 1778.

purpose was not manipulated and military factories went on for years while the primitive town expanded around, boosted by the beginning of the fortification works of the neighboring island (1760-69) [15], since then Nueva Tabarca, in an act of publicity of the new central and absolutist Borbon power. In 1786 the new emblem was placed above the gate, the date when the castle became part of the Crown of Carlos III.

In the middle of the 19th century the fort became a civilian property. The negotiations that began in 1855 ended in 1860 formalizing the surrender of the fort by the Ministry of war to the City Council of Santa Pola (this process can be seen in $[16,17])$ and for this reason plans were drawn which are copies of the interiors. Since then, the property suffered a series of reform works to make it suitable for the new and varied civil use. The most aggressive works were the destruction of the bulwark of the Duke of Arcos (1872-74), the partial demolition of the Southwest Tower and the opening of specific holes in the wall to open the doors of levante - East - and poniente - West - (1880). The front open shed and the four posts along the corners were also removed. The whole of it was used by the enterprise according to its double condition, as an open space (parade ground) and as a closed space (old fort). The square was used as a market, as a stage for shows and festival events and celebrations. As a property it was converted into a town hall, customs, the Guardia Civil headquarters (circa 18751975), court (circa 1884-1996), hospital (from 1835) and clinic (up to 1980) and library (until 1985), among other uses.

Throughout the last century and a half (circa 1850-1990), the first architectural conditions (refer to open and protective space) the ancient fortress became a milestone of singular characteristics in the memory of the people, while the second of the possibilities conveyed the idea that the whole set was destined to be the center of public life. Both aims are complementary to each other and have their historical justification in its location and origin, because the 
fort is at the beginning of the village and the township has spread behind it. On the one hand, the geographical position of the fort has always been very centric, as intended by its Renaissance concept. On the other hand, the military fort was the origin of a civil society, unlike other cities, where the town was built around it.

In the late 20th century the old fort was partially crippled, weakened in its structure and emptied of any use and content. The military use had given way to an administrative destination for which the property had become obsolete. The building was almost abandoned. It was the right time to act. And if at first the fort had been the military center, and later became the political center of the civil society, it could well be recuperated to become the center of the city's cultural life, as a reflection of the democratic society that appreciates and maintains it. From a military building it became a civilian center and finally to the cultural center it has been converted into.

\section{Plan for the rehabilitation of the fort (1990-2015)}

\subsection{First steps: reinforcements and intervention projects}

Throughout the last century and a half, this work has undergone many reforms as befitted each of the different purposes. These measures have involved mutilations with the progressive consequent deterioration of the building. The first works of consolidation aimed at recovering part of the primitive original appearance date back to 1973 (Figure 3), but the final shape of these works under a global project did not take place until the transfer of the town hall in 1989. The first projects were developed by architect Antonio Orts Orts and under his leadership the forge strengthening in the area of the old town hall, reparations of the interior facades and extension of the existing pavement of the yard were carried out [18]. The technical documentation suggested a number of improvements, but not the restoration of the items lost in the years of existence of the fort, such as the emergency gate, the bulwark or the south tower.

In the 1980s, the City Council proceeded to put up the south wing as the Archaeological Museum and Aquarium, hiring its own staff. Years later, in 1987, on the eve of the transfer of the municipal offices, architects Manuel Sempere Valero and Andrés Martínez-Medina developed a pilot study for the rehabilitation of the fortress. In it they pointed out at the advisability of recovering the primitive destroyed volumes and provide a cultural and participatory character to this property, so that the shifted political center (the City Council had moved to a building close to the sea) was replaced by a hub of common history knowledge: past and contemporary. A facility endowed with museums, exhibition galleries, and representative rooms detailed the program. Two years later, in 1989, the architect Juan Sempere Pérez drew up the blueprint in which cultural and museum uses of the property would be incorporated as intervention stages were defined [19]. (Juan Sempere Pérez (arch.) drafted some projects for the South and West wings.) 


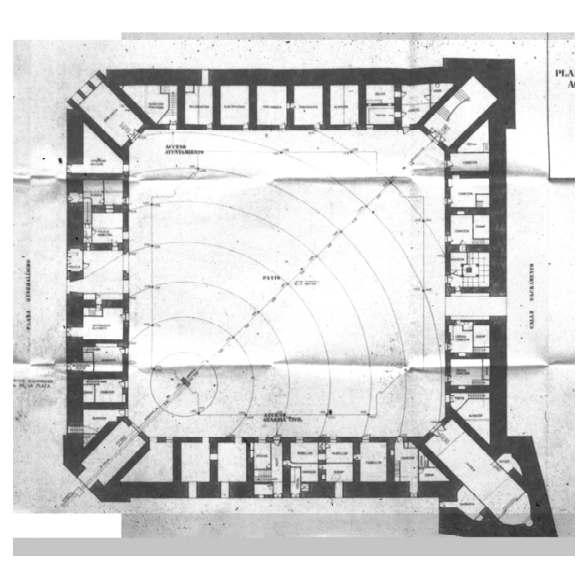

(a)

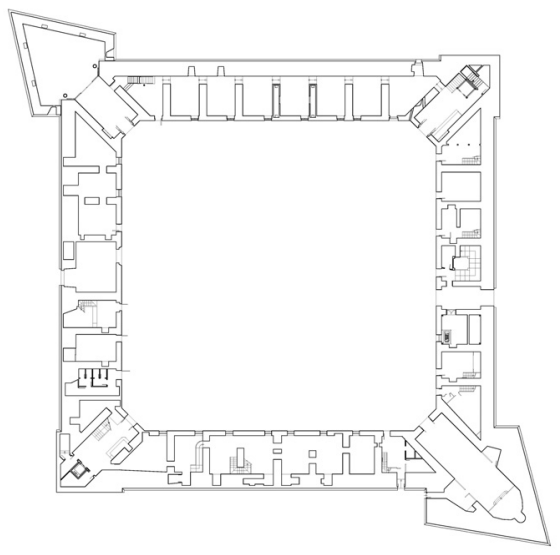

(b)

Figure 3: (a) Map of the State of the military fort in 1973 (A. Orts Orts). (b) Map of the current status of the Fort in 2000 (A. Martínez and M. Sempere).

Since then and through the following decade (1989-1998), works at different stages allowed the recovery of the silhouette of some walls, the prismatic body of the Southern tower and the original $\mathrm{Z}$ shaped portion of the main entrance; they also alleviated some of the problems suffered by the building. All this followed a parallel start-up process of the rehabilitated areas meant to become the Archaeological Sea Museum and associated research units (South and West wings). The last works that were carried out were the liberation of the North wall from the attached building and the conditioning of this wing to complete the cultural program. In fact, in the present document is detailed the action that has been aimed at reforming and adapting the entire North wing, where the offices of the old town hall are located, destined to be the new Sea Museum and Hall. This work covers the entire North of the Fort, from the tower of Palacio to the demolished bastion of the Duke of Arcos.

The proposal of intervention in this North wing had to face the challenge of engaging the museum program and the conference room inside a military building which primitive dwellings were reformed to develop administrative customer service functions (Figures 3, 4 and 6). The character of watertight cells of the old houses - that connected exclusively with the parade ground-had been altered by opening a series of holes allowing the communication of the different living areas converted into offices and counters. These steps were performed in the beams and walls and the sequence of the same had created two parallel corridors: one for the public, parallel to the wall, and another for staff, in the middle of the rooms. This new system of traffic, which operated for about a hundred year, had completely changed the initial approach of private and interior routes to each housing unit and direct access from these to the large courtyard. But this system of routes had also left a mark on the way inside the interior the municipal offices was used. 


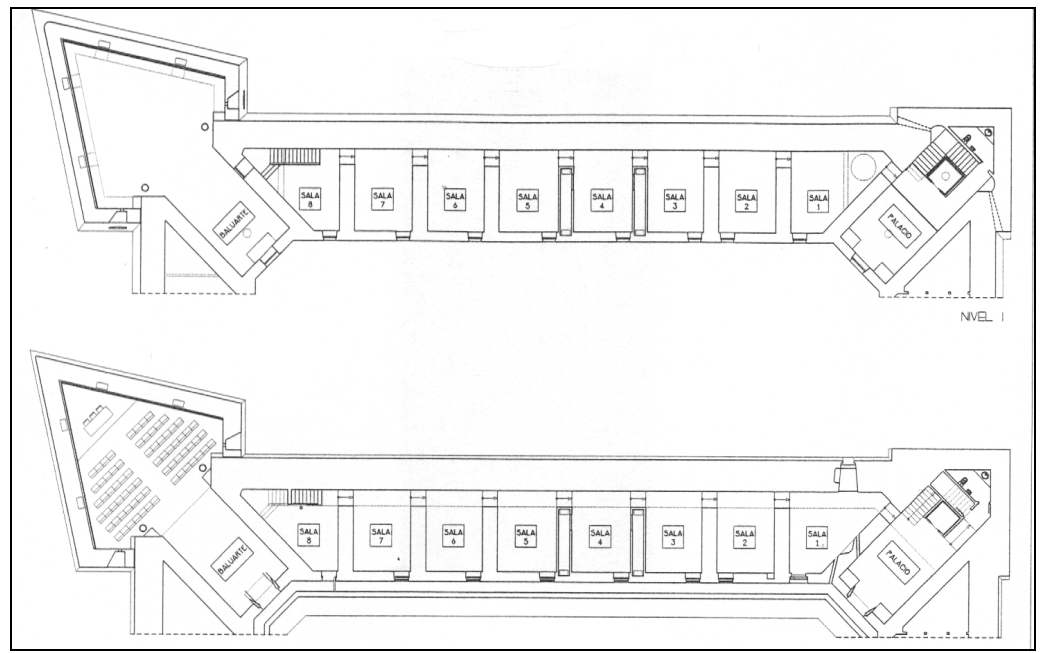

Figure 4: North wing rehabilitation project (A. Martínez and M. Sempere 1998).

The criteria for intervention were focused firstly on the recovery of the structural typology observing the distribution of the system of the bearing walls and, secondly on maintaining the destroyed parts, as closely as possible, to their original shape. Thus, it has located the new Museum of the Sea in the spaces formed by the Palacio tower and 8 adjoining rooms (which correspond to 8 ancient townhomes in this canvas) and has adapted the bulwark of the Duke of Arcos as the conference hall. In the project report this room is used for all kinds of events, including: the celebration of civil marriages in opposition to the religious ones that take place in the chapel across the diagonal of the ground.

\subsection{The decisions of the North wing project: a performance model}

The proposed intervention (Figures 3,4 and 6) addressed the action, clearly differentiating two zones. The first area, the most extensive one covered the entire North wing and included the tower palace and the eight contiguous habitats. The second one, a smaller area, focuses on the demolished bulwark of the Duke of Arcos. In the first area, the works of intervention for its rehabilitation as the new Museum of the Sea included tasks such as partial reconstruction, restoration and rehabilitation. In the second, intervention works for its conversion into a conference hall included, especially reconstruction work, restoration and repair. This project and the build (1998-2003) were carried out by architects A. Martínez-Medina and M. Sempere Valero [20].

With regard to works in the North wing, the future museum required the presence of a longitudinal corridor that crossed all buttressed walls, so he opted to maintain and strengthen the corridor attached to the lower surface of the wall, leaving this element seen in the nakedness of its masonry for easier understanding of the interior of the building as an old fortress to have on hand 
the exposed masonry walls. It has thus regained the volume of each of the former rooms, now converted into exhibition spaces arranged in series, and has restored its primitive type modulated order, transforming watertight spaces of yesteryear into a series of rooms connected by an internal passage, attached and parallel to the wall.

With a criteria of hierarchical logic, access to the new museum has been raised through the chamfer of the old palace, and released the height of the vaulted space and the new main staircase has been built, almost a cloistered path (reminding us of the typical Renaissance style), which revolves around the box free glass elevator. The entrance hall becomes a 'small palace' for the generosity of its space, the vaulted ceiling and the presence of significant elements such as interior balcony, the stairs and the newly discovered protection pockets (which go from Aid gateway Corp of guards to the palace main gate and the outer space of the same). From this reception room of the museum tours of the interior of the rooms begin ( 1 to 8 ) with a staircase at the opposite end of the wing, at the end of the perspective of the steps, allows communication between the ground floor and the first floor. The museum has a permanent collection on the lower level, where the spaces are prismatic and static, and allocates the upper level traveling exhibitions, where spaces are vaulted and more dynamic.

To complete the work of intervention all holes created throughout the 20th century have been filled with concrete, to bolster walls' resistance. These have been coated with a brick wall that consolidates the structure and allows for differentiation between vertical planes and curved vaults: the blue and yellow color applied on bastard mortar surfaces helps with the understanding of this and they refer us to historical chromatics (as valances remarking enhancing holes to the houses). In addition, they have recovered grades and historical levels, and the courtyard facade has been restored by blinding the intruding windows. The quartering found on the clay pavement was remade and items hidden, due to the passing of time, were discovered: the Aid gateway, the interior gunboats, corresponding to a spiral staircase with access to the roof and the geometry of the Tower of the Palace.

In this process full care has been taken so that itineraries are practicable for people with disabilities. In addition to the elevator, located as an independent and autonomous device (showing their mechanical devices), have solved the gaps between all the rooms with ramps that match the width of the transoms walls, so that each room (both ground floor and upper floor) is located at a different height, coinciding with historical levels of its wooden floors, now replaced by concrete. The corridor attached to the wall solves these difficulties: the connection between rooms and the gaps between them shows the masonry of the perimeter wall and serves as a tunnel to all ducts (Figures 5 and 7). For interior comfort the building has been equipped with air conditioning, where pipes pass through the gap in the old smokestacks of each home, from the ground floor to the roof. The North wing has been updated in its entirety without the facility having damaged the constructive elements of the old fort and without these being seen, which favors concealment the sharp reading of the geometry of military engineering that inspired this fortress. 

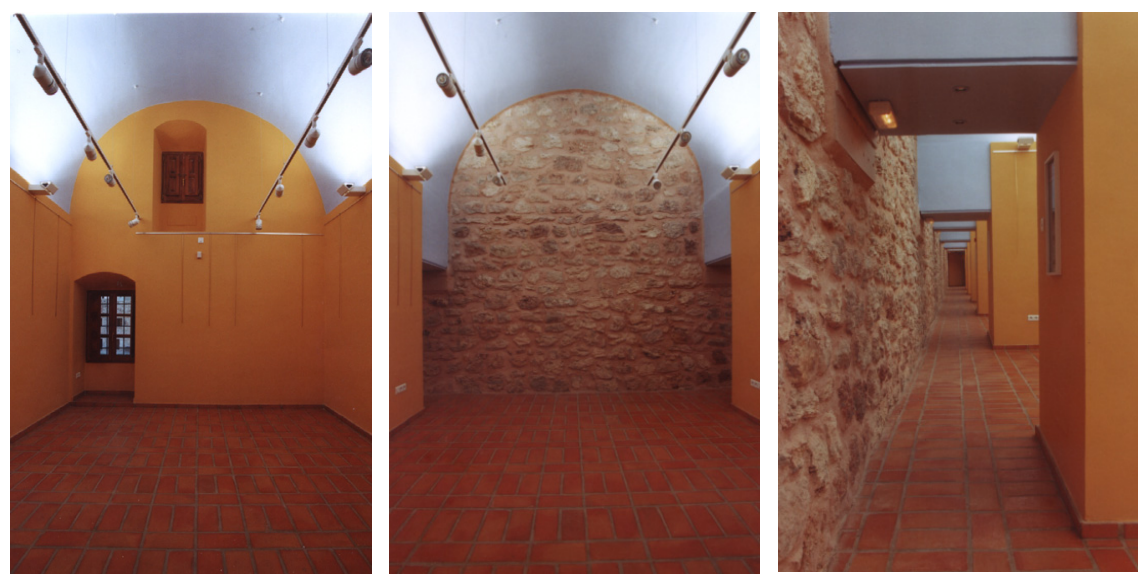

Figure 5: Interior of the North wing rooms (A. Martínez and M. Sempere, 1998-03).

With regard to works in the bulwark, the most important issue was to rebuild the demolished outer volume as faithfully as possible to the genuine. This challenge was not difficult because, although there were no pictures or precise surveying at the time of its demolition (1872-74), they counted on three types of documents: 1st) the plans of the eighteenth and nineteenth centuries, 2nd) the measurable traces its foundation discovered in archaeological campaigns in 1997-98, and 3rd) all starts and berthing of the flared molding of the perimeter wall were preserved. The first document defined the volume and gunboats, the second data showed traces of starting the external walls and the third witness stated the slopes of the outer vertical canvases.

With this evidence they could proceed with the almost archaeological reconstruction of the envelope of the bulwark of the Duke of Arcos (Figures 6 and 8), for which it is necessary to combine traditional techniques of the wall of ordinary masonry, placed by rows, with reinforcement of a hidden structure of reinforced concrete that served to lift the roof and the creation of a larger room. In the bastion it has remained the vaulted historic space preserved to date and in the new part thereof, on the trace of the arrowhead, they chose to define an honest space, of a plant identical to its past marks, with natural light suspended ceiling, skylights which camouflages itself in the continuous finishing merlon of the wall. Indirect light fills the space not restored of the demolished bulwark, drawing an invisible curtain denouncing its destruction: the sectional wall, showing its masonry, becomes the historical room flapper to the current conference hall.

If outside the strong volume discreetly is indicated the difference between the historical and new factories, emulating certain continuity with the past, inside things have, in contrast, changed. The bulwark, now converted into the Conference Hall, has been coated with similar criteria to the entire intervention. The colors of the walls and vaults have been preserved, the facilities have been 


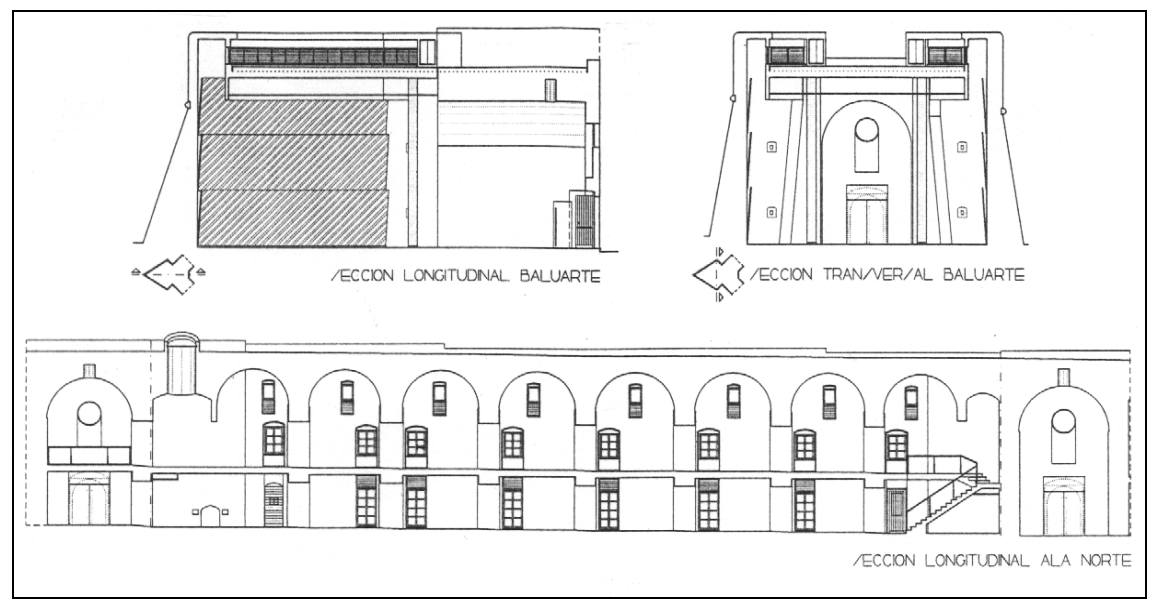

Figure 6: Sections of the rehabilitation project of the North wing (1998).

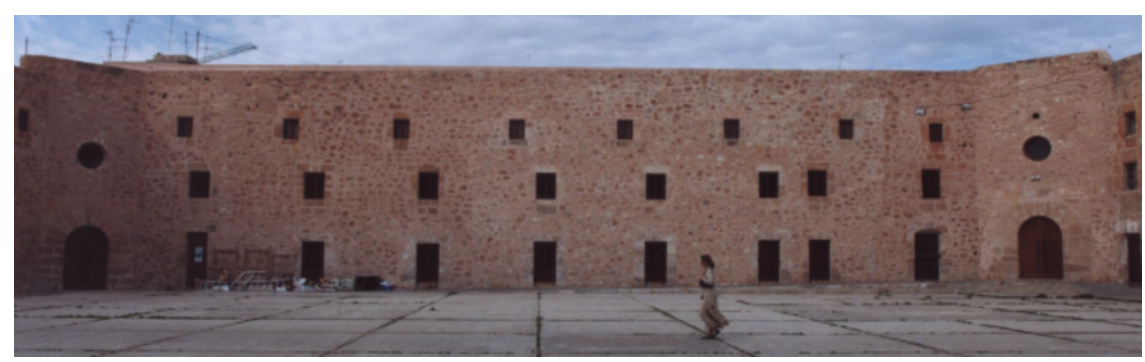

Figure 7: The final state of the façade to the parade ground of the North side.
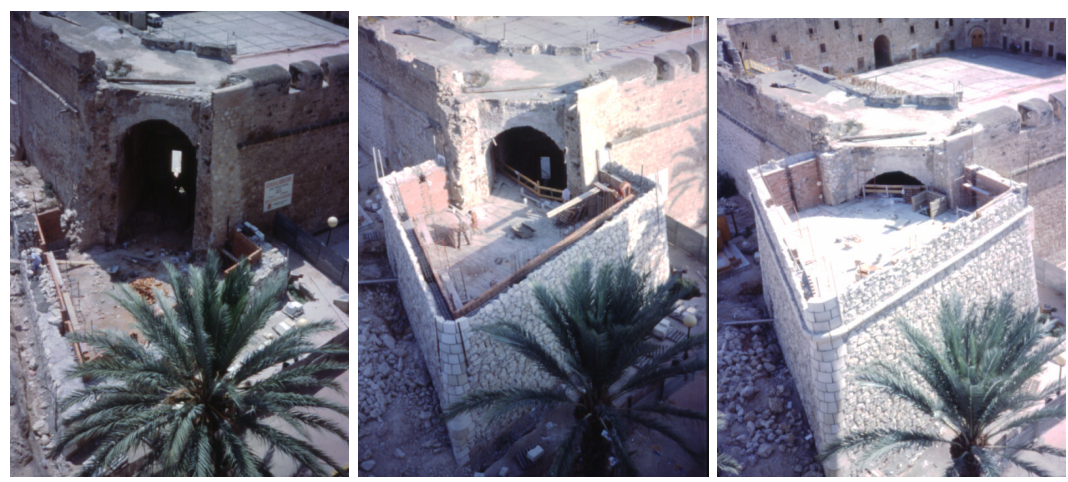

Figure 8: Process of reconstruction of the volume of the bulwark (19982003). 
hidden and the entrance system has been recovered with gangways through a large gap adjusted after the stones of the entrance arch. And on the new building of the bulwark they have used noble materials: natural stone with a triangular cutting for the floor, cork vertical surfaces and wood panels for the walls, steel sheets for the pillars and aluminum slats for the roof. The finishing adds value to the space with the vocation of public events celebrated there.

\section{Conclusions: intervention respectful towards its memory}

The intervention on the fort has tried to be as respectful as possible towards the past without diminishing its importance for the future. Meeting this challenge while maintaining an extremist attitude, as advocated by John Ruskin, would turn the fort into an archeological site. It seems more appropriate to rehabilitate the building by rebuilding and restoring than allowing a new demolition. Because this intervention is part of a larger project, covering both the fortress and its surroundings, and its aim is to recuperate the city center where it was born, for its citizen. The open esplanades will be used for daily leisure and ritual spectacle of traditions, while the architectural volume of the fortress will house a collection of museums (archaeological, ethnographic and traveling exhibitions) that can be summarized in a village museum which will house a part of its social, cultural and artistic life.

The cities where we live are presented to us as the deposit layers that consist of different architectures and engineering; these works are not scattered fossil remains. Although the implementation of this heritage was bygone, their presence and use make this our present. The passage of time in the city, the memory of the people who populated it becomes visible in its urban fabric and buildings that constitute it, as if they were the successive layers sediment throughout history. There is an identity between the city and its architecture, and both are a social event, reflecting the civilization that promotes them. In this sense, both entities accumulate a double meaning: as a historical fact (document) and as contemporary reality (actor). A historical fact because architecture built in the past witnessed other cultures. A contemporary reality because, in its tenure to date, we still keep them in use. In the words of François Choay, monuments have a double status: they are stewards "of knowledge and pleasure" [21]. Our cities cannot renounce their past because this is highlighted in their building heritage, whether it is anonymous or authored.

It is likely that the purpose for which the military fort that was in use for three centuries (1557-1850) was built, no longer makes sense, nor does the administrative and multipurpose of the last century and a half (1850-1990); but this society from its sensitivity and respect for the cultures that have preceded it, can recover it and give it a new meaning (1990-2015). The architectural heritage is not an inventory of items that are exposed in a museum and is collected in a catalog. The museum is the city itself, although this is subject to continuous changes that alter their appearance. These transformation processes are inherently linked to our post-industrial society: it is produced to consume and consumed to produce even more, which means an excessive way of 
understanding wellbeing as several risks and dangers are run. If architecture becomes a commodity, its value will only be economic and, consequently, the cities and their property assets are no longer repositories of a common memory because both would be subject to market processes. And if contemporary society does not know how to find a balance between their needs and the recovery of its historical heritage, may one day not remain bygone architecture to enjoy and stories to convey.

\section{References}

[1] Bevià I García, M.; Martínez-Medina, A., "Una máquina para la guerra: el fuerte militar, de la estrategia defensiva a la táctica proteccionista" en Sánchez Fernández, M.J. (coord.), II Congreso Internacional de Estudios Históricos. El Mediterráneo: Un Mar de Piratas y Corsarios, ed. Ayto. Santa Pola, Alicante, 2002; pp. 243-251.

[2] Gozálvez Pérez, V., Santa Pola. Urbanismo. Economía. Población, ed. Círculo de Economía, Alicante, 1976.

[3] Cámara, A., Fortificación y ciudad en los reinos de Felipe II, ed. Nerea, Madrid, 1999.

[4] Banyuls I Pérez, A.; Boira I Maiques, J.V.; Lluesma I Espanya, J.A., Arquitectura i control del territori. La defensa del litoral de la Marina Alta al segle XVI, ed.: Ayto. de Benissa e Inst ${ }^{\circ}$ Juan Gil-Albert, Alicante, 1996.

[5] Aguilar Civera, I., La fachada litoral. Naturaleza y artificio. Mapas, cartas, planos y vistas de la Comunitat Valenciana, 1550-1868, ed. Generalitat Valenciana, Valencia, 2012.

[6] Boira Maiques, J.V., Las torres del litoral valenciano, ed. Generalitat Valenciana, Valencia, 2007.

[7] García Mas, A.; Martínez-Medina, A., "La frontera marítima fortificada: de la vigilancia a la señalización (XVI-XIX)", Rodríguez Navarro, P. (ed.), Defensive Architecture of Mediterranean (XV to XVIII centuries), 2 vols, ed. UPV, Valencia, 2015; pp. 61-68.

[8] Giorgio Martini, Francesco di, Trattati di Architettura, Ingenieria e arte Militare (II), ed. Il Polifilo, Milán, 1967 [s. XVI].

[9] Barozzida Vignola, Giacomo; Cataneo, Pietro, Trattati di Architettura (volume quinto, parte seconda), ed. Il Polifilo, Milán, 1985 [s. XVI].

[10] Cardone, Vito, "Pedro Luis Escrivá: Forma i Funzione nel disegno delle fortificazioni”, rev. Expresión Gráfica Arquitectónica, $\mathrm{n}^{\mathrm{0}}$ 7, Valencia, 2002.

[11] Bevià i Garcia, M.; Camarero Casas, E., "Arquitectura militar renacentista" en AA.VV., Ayudas a la Investigación, 1984-1985. II: Arte, Arqueología y Etnografia, ed. Inst ${ }^{\circ}$ Cultura Juan Gil-Albert, Alicante, 1988.

[12] Historical Archive Services of the Army (ASHE), Madrid. 
[13] Deretz, Alejandro, "Planos y Perfiles del castillo de Sta Pola en que se manifiestan sus pisos Inferior y Superior", Valencia, August 1778 (exp. A01-05 and 06).

[14] Tomás de Enguinados, July 1855 (A-01-04)

[15] Gozálvez Pérez, V., "La formación del núcleo urbano de Santa Pola (siglos XVIII-XIX)" en AA.VV., I Congreso de Historia Local: Nuestra Historia, ed. Ayto. de Santa Pola, Alicante, 1999; pp. 151-169.

[16] Sánchez Fernández, M.J.; García Mas, A., Historia del Castillo-Fortaleza de Santa Pola $(s \cdot X V I-X X)$, ed. Ayto. Santa Pola e Inst ${ }^{\circ}$ Cultura Juan GilAlbert, Alicante, 1990

[17] Bonmatí Medina, R., Santa Pola. Siglo XIX, ed. Autor, Alicante, 1991.

[18] Historical Archives of Santa Pola. Orts Orts, Antonio: "Proyecto de restauración de muro en el Castillo de Santa Pola", March-May 1973.

[19] Historical Archives of Santa Pola. Sempere Pérez, J.: "Anteproyecto de Rehabilitación del Castillo de Santa Pola”, June 1989 hasta 1998.

[20] Historical Archives of Santa Pola, Martínez Medina, A; Sempere Valero, M., "Proyecto de rehabilitación para museo y salón de actos del ala norte del castillo-fortaleza de Santa Pola" (various projects), 1998.

[21] Choay, F., Alegoría del Patrimonio, ed. Gustavo Gili, Barcelona, 2007 [1992], p. 194. 